\title{
Reflections and Directions for Research in Refugee Studies
}

DOI:

10.1080/01419870.2020.1677928

\section{Document Version}

Accepted author manuscript

Link to publication record in Manchester Research Explorer

\section{Citation for published version (APA):}

Bloch, A. (2020). Reflections and Directions for Research in Refugee Studies. Ethnic and racial studies. https://doi.org/10.1080/01419870.2020.1677928

\section{Published in:}

Ethnic and racial studies

\section{Citing this paper}

Please note that where the full-text provided on Manchester Research Explorer is the Author Accepted Manuscript or Proof version this may differ from the final Published version. If citing, it is advised that you check and use the publisher's definitive version.

\section{General rights}

Copyright and moral rights for the publications made accessible in the Research Explorer are retained by the authors and/or other copyright owners and it is a condition of accessing publications that users recognise and abide by the legal requirements associated with these rights.

\section{Takedown policy}

If you believe that this document breaches copyright please refer to the University of Manchester's Takedown Procedures [http://man.ac.uk/04Y6Bo] or contact uml.scholarlycommunications@manchester.ac.uk providing relevant details, so we can investigate your claim.

\section{OPEN ACCESS}




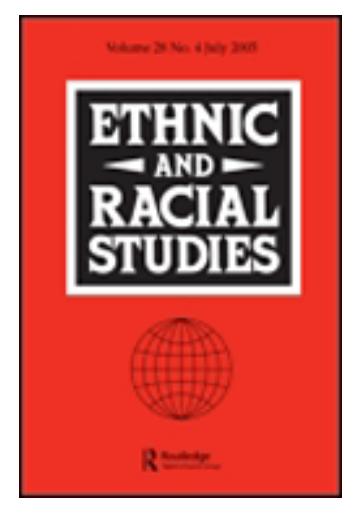

\section{Reflections and Directions for Research in Refugee Studies}

\begin{tabular}{|r|l|}
\hline Journal: & Ethnic and Racial Studies \\
\hline Manuscript ID & RERS-2019-0175.R2 \\
\hline Manuscript Type: & Original Manuscript \\
\hline Keywords: & $\begin{array}{l}\text { Refugee Studies, Durable Solutions, Second Generation, Forced } \\
\text { Migration, Refugee policy, borders }\end{array}$ \\
\hline
\end{tabular}

\section{SCHOLARONE \\ Manuscripts}




\title{
Reflections and Directions for Research in Refugee Studies
}

\author{
Alice Bloch1 \\ Department of Sociology, University of Manchester, Manchester, UK.
}

\begin{abstract}
This paper reflects on how refugee studies has developed and identifies areas for future research. First, the paper sets the scene through an overview of refugee protection regime and on patterns of displacement. Second, the development of theories that try to explain refugee movements are explored. Third, the policy focus of refugee studies and the inherent tensions are examined. This is followed by an exploration of three areas for further research: durable solutions, borders and bordering practices and the intergenerational impacts of refugee migration. These areas allow for multi-level analyses, expose the tensions between structure and agency, power and resistance and the post-colonial world order, and place emphasis on everyday lived experiences. The paper argues that social science disciplines have an important role to play in the field of study but need to include historical analyses and engage in inter-disciplinary alliances to enable shifting paradigms.
\end{abstract}

\section{ARTICLE HISTORY}

KEYWORDS

Refugee studies, Forced migration, Borders, Durable solutions, Second generation, Refugee policy

Refugee studies emerged as an area of scholarship in the 1980s and has been influenced by the demands of nation states, of humanitarian organisations and by changing mobilities (Castles, 2003; Chatty and Marfleet, 2013). Social science research has made significant theoretical, policy, practice and empirical contributions to refugee studies and its wider reaching descendant, forced migration studies. The field of scholarship is necessarily part of an inter-disciplinary and transnational project with blurred disciplinary lines. No one discipline can adequately grapple with the range of factors structural and local - that are inherent in this area of work and so each needs to inform the other so that research can shed light on the causes of refugee migration and on the different and complex ways that refugee migration affects individuals, families, groups, communities, countries and regions.

There is a long history of seminal research that has and continues to influence scholarship. For example Harrell-Bond's (1986) work on refugees as a resource, Malkki's (1992) work on sedentary bias that critiques the framing of mobility as the exception and the work by Zetter $(1991 ; 2007)$ on bureaucratic labels. However within refugee studies there is a tendency to reinvent the

\footnotetext{
${ }^{1}$ Email: alice.bloch@manchester.ac.uk
} 
wheel (Hathaway 2019). Such a criticism can be directed at most areas but looking back before going forward offers essential context and an historic understanding of pre-existing knowledge to anchor new ideas and to avoid the repetition of mistakes. This is not to ignore some of the positive developments including the shift to critical analyses of sex and gender and post-colonial framings of the field and in the expansion of participatory models of research, policy and practice.

This paper, in a modest way, sets out to make a contribution by looking backwards and forwards. As a review piece it reflects on how the field of research has developed but it also identifies areas going forward. Of course these are subjective and reflect my own knowledge, interests and concerns. Others writing this paper would prioritise different facets of the past, for example the changing patterns and actors within the humanitarian field, and the future priorities notably the impact of climate change on forced displacement. There is much debate to be had. The paper is in four main sections. The first section sets the scene, providing the context of the international refugee protection regime and on contemporary patterns of displacement. The second part explores the development of theory with a focus on the theories that try to explain refugee movements. Although there is also a large body of theoretical and empirical literature on assimilation, integration and refugee settlement, this work usually emerges from national contexts and is generally applied to those specific migratory and social policy settings so is too specific for the objectives of a review article. The third section examines the policy focus of refugee studies and the complex and sometimes competing interests of stakeholders. The final section identifies three crucial areas: durable solutions, borders and bordering practices and second generation people from refugee backgrounds arguing that these areas need to be central to research and scholarship going forward. Durable solutions continue to frame international responses to refugee movements but continue to fail, partly because states are able to renege on their international obligations, as they implement increasingly restrictive domestic policies. Borders and bordering practices are significant because they encompass not only the physical space of the border but a host of areas that relate to borders including surveillance (external and internal), fences, journeys, death, state sanctioned injury, agency and power at the macro and micro levels. The third area of further research, are the longer-term impacts of refugee migration. Relatively little is known about the various and complex ways that the children of refugees are affected by their parent's experiences. My own collaborative research highlights the need for more social science research on the intergenerational aspects of refugee migration and how these shape everyday lives (Bloch et al, 2015).

\section{Contemporary context}

The international framework for refugee protection is the 1951 Geneva Convention and the 1967 New York Protocol Relating to the Status of Refugees. Developed in the post-WWII era, and restricted to refugees from Europe and those who had emerged as a result of events occurring before January 1st 1951, the Geneva Convention defines a refugee as a person who, 


\begin{abstract}
Owing to a well-founded fear of being persecuted for reasons of race, religion, nationality, membership of a particular social group or political opinion, is outside the country of his nationality and is unable, or owing to such a fear is unwilling to avail himself of the protection of that country; or who, not having a nationality and being outside the country of his former habitual residence as a result of such events, is unable or, owing to such fear, is unwilling to return to it.
\end{abstract}

Although 30 million people were displaced in Europe the regional focus ignored other mass displacements of that era, notably the partition of Indian in 1947 that left 14 million people displaced with little international assistance. The New York Protocol Relating to the Status of Refugees, in 1967, removed the geographical and temporal limitations of the refugee definition. This was at a time when the majority of colonised states had already gained independence.

In addition to the international protection framework, there are also regional laws and standards that expand the grounds for protection. The Organisation of African Unity Convention Governing the Specific Aspects of Refugee Problems in Africa (OAU), in 1969, has its origins in the conflicts that accompanied the end of the colonial era in Africa. People fleeing civil disturbances, widespread violence and war are entitled to claim refugee status in states that are parties to the OAU Convention regardless of whether they have a well-founded fear of persecution. The 1984 Cartagena Declaration focuses on protection in the Latin American region and includes persons who have fled their country, 'because their lives, safety or freedom have been threatened by generalised violence, foreign aggression, internal conflicts, massive violation of human rights or other circumstances which have seriously disturbed public order' (Reed-Hurtato 2013). Most recently has been the Kampala Convention (adopted in 2009) that established the responsibilities of states for the protection of internally displaced people (IDPs) as a consequence of natural or human made disasters including climate change.

The numbers of forced migrants have peaked and troughed over the decades since the end of WWII. Major sites of displacement globally have included: the Algerian war of independence that displaced 1.2 million from the mid-1950s to the early 1960s, the Biafran war where 2 million people were displaced between 1967 and 1970, the Bangladesh war of independence displaced 10 million Bengalis from east Pakistan to India in 1971, the Soviet invasion of Afghanistan in 1979 led to the displacement of 6.3 million Afghans to Iran and Pakistan, civil war in Mozambique displaced 5.7 million internally and to Malawi between 1976 and 1992, civil wars in the central American countries of Nicaragua, El Salvador and Guatemala displaced 2 million people mostly to neighbouring countries in the 1980s, the Rwandan genocide of 1994 displaced 3.5 million (2 million to Zaire, Uganda, Tanzania and Burundi), the break up of Yugoslavia in 1992-95 displaced 2.5 million, civil conflict in Colombia has led to the displacement of almost 6 million people from 2000, the war in Syria has displaced more than 13 million since 2011 (5 million are 
refugees outside of Syria mainly in Turkey, Jordan and Lebanon) and more than 2 million people were displaced due to the civil war in south Sudan between 2013 and 2015.

The numbers of forcibly displaced people are at their highest ever and more are outside the refugee protection framework. At the end of 2018 there were 70.8 million forcibly displaced people of whom 25.9 million were refugees, 41.3 million were internally displaced people (IDPs) ${ }^{i}$, an additional 3.5 million people were asylum seekers and 10 million were stateless. Most displaced people stay in their region of origin (UNHCR 2018) reflecting the geography of forced migration, the costs and risks of longer distance travel and the political agenda of Europe, north America and Australia where borders, barriers, racism, exclusion and hostility are a central part of the maintenance of the post-colonial world order (Chimni 2009).

The debates about the limitations of the refugee protection system are well rehearsed with some arguing for the specificity of refugees within the forced migration paradigm (Hathaway 2007) while others reflect on these limitations given the numbers of IDPs (Cohen 2007) or the need for an approach more focused on human rights (de Wind 2007). These debates reflect the legal definitions and clear-cut categories versus the more messy realities of lived experiences that are captured by sociologists and anthropologists (see Zetter 2019 for an overview). Regardless of positioning in this debate, most displaced people are not refugees and are outside of the protections offered by refugee status.

\section{The development of theory and concepts}

Attempts to theorise refugee migration are relatively recent. In contrast, there is a long history of theoretical work on migration, dating back to the late $19^{\text {th }}$ century and emerging from different academic disciplines. The early theories focused on economic drivers, including the needs of capitalism, but have become more complex. Migration is analysed in relation to the global systems and networks that have developed as a consequence of migration, that facilitate more migration and create linkages in a globalized world. Massey et al. (1998) argue that migration research is a set of disjointed and uneven theories. Different theories may have some explanatory value but there are too many limitations for any one theory to be generalizable (Arango 2002). Although theories of migration incorporate some factors that are relevant for refugee migration, they do not highlight the experiences of refugees in the wider analysis of migration. These experiences will include both similarities and differences but need to be considered at every stage of the process beginning with the decision to migrate (Erdal and Oeppen 2018).

The early attempts to theorise refugee migration focused on the specificity of the refugee experience. Kunz $(1973 ; 1981)$ proposed a kinetic model of refugee migration positing that the lack of a positive reason for migration is the factor that distinguished refugees from other migrants. Kunz theorised the relationship between the reasons for refugee flight, the circumstances of refugee flight (whether it was an acute situation or anticipatory), whether the refugee person might be able to or want to return to the country from which 
they have fled and what the relationship might be between these factors and settlement. Refugee movements should not be viewed as individual and distinctly different occurrences but as reoccurring phenomena, with identifiable and often similar causes, which shape patterns of mobility. Though not tested empirically and criticised for its simplicity, an important contribution of Kunz's model was that it paved the way for more complex attempts at theorization. These more nuanced approaches incorporated not only refugees but other groups that are also persecuted or potentially vulnerable that characterise the wider and more extensive category of forced migration.

Theoretically it was the work by Richmond (1993) that began to grapple with a more complex analysis of forced migration with less clearly defined lines of cause and effect; push and pull; voluntary and involuntary effectively challenging the dichotomies that dominated the field. Critiquing the idea that refugees were involuntary and other migrants voluntary, Richmond (1993) argued instead that the majority of population movements are a complex mix of political, economic, environmental and social determinants that meld together in different combinations and interact with structural constraints to migration - such as visa requirements - or structural facilitators that enable migration to occur. Therefore the idea that voluntary migrants are entirely free and autonomous while involuntary migrants have no room to exercise choice is replaced with the notion that there is a continuum between proactive and reactive migration, where reactive migration is more associated with forced migration.

Also challenging binaries is Van Hear's (1998) work on mixed motives for migration that demonstrates the ways in which migration is rarely either voluntary or forced. Instead, almost all migration involves some compulsion and some choice though of course some people have more choices than others and some decide or are compelled not to move (Van Hear, Brubaker and Bessa 2009). Among those that do migrate, different stages of the migratory process may also include varying degrees of compulsion. For example the initial movement may be forced but onward mobility from transit countries may be motivated by factors that include economic opportunities and family ties so become associated more with choice than force (Van Hear, Brubaker and Bessa 2009). Mixed motives have been further complicated by mixed migrant flows where asylum seekers move alongside other migrants. Mixed flows can make it hard to distinguish between those who are entitled to protection, under the 1951 Geneva Convention, and those who are not and therefore easier for wealthier states to label migrants as illegal. Mixed migration flows as a concept was developed under the description 'migrationasylum nexus' to highlight fluidity as opposed to rigid binaries throughout all stages of the migration process creating differences between policy makers, including UNHCR, who emphasized the dichotomies and academics who focused on complexities and fluidity (Castles 2007; Scheel and and Ratfisch 2014).

Van Hear, Bakewell, and Long (2018) focus on migration drivers as an advance on the traditional push-pull model of migration. Drivers are delineated into: predisposing, proximate, precipitating and mediating. 
Predisposing factors reflect the context and include structural circumstances that might result in migration. Proximate drivers reflect the conditions in both countries and regions of origin and destination. Precipitating drivers lead to migration or the decision not to migrate. These are normally linked to an event or events and can include the factors that are normally associated with refugee migration including civil war, war or military invasion and/or persecution. Mediating factors will be the conditions that facilitate or constrain migration such as economic resources, social networks and migration regimes. The role of structure highlights how migration is one possibility but mobility can and is prevented by sending, transit and receiving countries where state imposed structural barriers in the form of borders and bordering practices prevent movement. The tensions between structure and agency are necessary for understanding forced migration (Bakewell 2010). These mediating factors are important in explaining why the world's poorest do not migrate (Castles 2003). Migration drivers work together, rather than in isolation, to produce the 'driver complexes' that shape migration (Van Hear, Bakewell and Long 2018, 934).

Refugee flows, like other population movements, can be viewed as events that result from broad historical processes including the effects of the postcolonial era. Any meaningful analysis needs to locate the contemporary within the historic. Mass displacement has and does shape the modern world (Marfleet 2013) although historians have written relatively little about refugees in this context (Gatrell 2017). Refugee studies as a field of study, with some exceptions, rarely engages with historical contexts partly because each refugee-producing situation is regarded as unique and so the lessons learned from the past are rarely applied or reflected on (Marfleet 2007). Of course the reality is very different, history is central to refugees and visa versa. Gatrell (2017) highlights the role that history has in migration routes. For instance, migrant labour destinations have paved the way for future refugee movements such as Bosnian refugees going to Germany, Austria, Sweden and Switzerland (Valenta and Strabac 2013) and where refugee patterns of migration are linked to historic ties including former colonial connections (Havinga and Böcker 1999).

Indeed, Banerjee and Samaddar (2019) argue that what is required is a critical post-colonial approach that integrates history with an understanding of the specific aspects of the post-colonial political and social structures. While critical scholars increasingly engage with colonial legacies and the on-going post-colonial racialization of migrants, the organisations that fund research continue to see each refugee 'crisis' as a unique event that requires a policy analysis and a policy intervention to solve the problem. Policy makers stifle theoretical development partly though their use of categories and labels (Bakewell 2008). Moving away from a state centred approach and instead towards lived realities, Erdal and Oeppen (2018) argue that a complete rethink of migration decisions is necessary placing volition - that depends on the range and nature of available alternatives - at the centre. The objective would be to focus on 'voluntariness, choice and alternatives' rather than a dichotomy between voluntary and forced (Erdal and Oeppen 2018, 982). Reframing the field of study to include otherwise excluded groups in the 
analysis and those who do not move would offer greater opportunities for theorization (Lubkemann 2008). Refugee studies is more theoretically useful as part of a large inter-disciplinary project alliances which are essential in order to advance the field (Vannini et al. 2019).

\section{The focus on policy}

Refugee studies, as an area of scholarship has been orientated towards policy driven research (Gatrell 2017). The focus on policy interventions can create an uncomfortable relationship between research agendas, the purpose of research and the target audiences. The knowledge produced can be based on research funders' institutional ideas of what has policy relevance (Bakewell 2008). Moreover, research is generally funded and carried out by institutions in the richer countries and this maintains the power of the hegemonic state within the post-colonial world order (Chimini 2009). The richer countries dominant the international agenda where policies are designed to contain forced migrants, often in the region of origin, and is part of what Chimini $(2009,20)$ describes as the western project of global dominance. The links between knowledge production and power and the voices that are heard and listened can be tainted by post-colonial racisms (Chimini 2009).

Policy and politics can rarely be separated from the research carried out by academics that has become enmeshed in competing and conflicting priorities. Tensions include a moral and ethical positioning about the value of research and importantly who benefits. While these concerns are not restricted to research in the field of refugee studies, Turton argues that it is hard to justify research into 'situations of extreme human suffering' $(1996,96)$ where positive change does not form an explicit part of the research agenda. In fact Mackenzie, McDowell, and Pittaway maintain that research can only be ethical where it results in 'reciprocal benefits for refugee participants and/or communities' (2007, 301), which means facilitating agency and capacity building. Moreover, the 'dual imperative' placed on academics to carry out research in refugee studies that is academically and methodologically rigorous while at the same producing knowledge that protects refugees and influences policy (Jacobsen and Landau 2003) can limit the type of research that is carried out and the categories and analysis applied.

The construction and analysis of research using categories defined by policy interests, argues Bakewell (2008), limits possibilities for engagement with social processes and as noted above, inhibits the development of theory. Although categories are bureaucratically useful, they are also constraining (Zetter 1991; 2007). Certainly the legal definition of a refugee has shaped but also restricted the conceptualisation of the field. Who is applying the label and 'what the discursive work of those labels entails' (Erdal and Oppen 2018, 993) must be critically interrogated. These labels map onto categories such as refugee, asylum seeker, irregular migrant, and are 'not merely an issue of semantics. Categories have consequences' (Crawley and Skleparis 2018,12). Most obvious are the rights and protections afforded to refugees at one end of the forced migration spectrum and the vulnerability and deportability of undocumented migrants and refused asylum seekers at the other end. Categories are also malleable; a refugee in one place might be an 
undocumented migrant somewhere else (Fitzgerald and Aran 2018). Moreover, not everyone who might meet the 1951 Geneva Convention definition of a refugee will apply for and/or acquire refugee status. Decisions and strategies are made for complex reasons and often ones that are expedient (Bloch and McKay 2016). There is mobility between the categories and statuses that dominant policy and political discourse (Bloch, Sigona and Zetter 2014). The status applied by states and institutions expose the disjuncture between state categories and perceptions of self (see Zetter 2019).

Crawley and Skleparis $(2018,60)$ call for engagement with the 'politics of bounding', which are the ways in which categories are constructed, the reasons and the effects. By analysing politics, power and process it may be possible to challenge the application and impact of categories and to include the excluded (Crawley and Skleparis 2018). Of course there is a case to remove categories and the power that states have by using them but this would require a complete overhaul of international protection and the role of the nation state in determining asylum which in the present climate would doubtless result in less rather than more protection. Unless there is a radical approach of global open borders and the upholding of human rights everywhere the danger would be greater exclusion not inclusion. There is a strong case to be made for more critical analysis, outside the confines of the institutional and legal frameworks that can and do impact on research and scholarship.

\section{Research and scholarship going forward}

The paper, so far, has considered some key aspects in the development of refugee studies as an area of scholarship. The rest of the paper focuses on substantive areas that are, in my view, central to the research field going forward. These areas are: durable solutions, borders and bordering practices and the experiences of second-generation people from refugee backgrounds. Others will have selected different areas depending on a number of factors including their disciplinary backgrounds, their substantive research areas and interests and the geographical areas that they work in. In selecting these three areas I am highlighting what I see as some of the key challenges for the field: first on- going failures and a rigidity in approach (durable solutions), secondly the ways in which a pre-occupation with controlling immigration has relevance far beyond the physical space of the borders (borders and bordering) and thirdly the need to take a longer term perspective by considering, not only the immediate crisis, but the extended impacts of refugee backgrounds (generations) and their intersections with transnational and diaspora studies. For social scientists these three areas are of interest and importance because collectively they offer insights into different levels of analysis (macro, meso and micro), expose the tensions between structure and agency, power and resistance and the world order, and place emphasis on everyday lived experiences. These everyday experiences so often become subsumed by the focus on the ways in which policy and practice responds to crisis.

Durable solutions 
Global forced migration and displacement is constantly changing. However, the concepts used and the solutions proposed remain largely unchanged. Durable solutions have been a central part of UNHCR's mandate since its inception with the focus on resettlement to third countries, repatriation and the local integration of refugees in countries of first asylum. Scholars have repeatedly highlighted the failings of these 'solutions', devised for refugees in Europe post-WWII and not fit for purpose in the contemporary world of growing numbers, IDPs and protracted displacement. The reluctance of states to participate meaningfully in resettlement and/or local integration and the sometimes devastating consequences of repatriation all points to systemic failures (Chimni 2004; Majidi and Schuster 2019).

More and more people are living in protracted refugee situations. A protracted situation refers to those who have been in exile for more than five years and where there is no prospect of a durable solution (Crisp 2002). Around twothirds of the world's refugees live in protracted situations of extended exile; current solutions are not in fact solutions (Hyndman and Giles 2019). At the end of 2016, 11.6 million refugees were in protracted situations of which 4.1 million had been in this situation for at least 20 years. Afghan refugees in Pakistan and the Islamic Republic of Iran has involved more than 2 million people and has been going on for more than 30 years. These are hardly exceptional situations - in fact they are arguably the norm. These protracted situations are accompanied by a reduction in the numbers of refugees resettled. Globally just over 100,000 refugees were resettled in 2017 clearly highlighting the deficit between need and response. This deficit illuminates the failures of the system where the wealthiest states continue to resist responsibilities. It also exposes the multi-level selection within the system where UNHCR put forward cases for resettlement and nation states may decide who to resettle based on their preferences which might be country of origin or perceived capacity for integration through measures such as language skills (Beirens and Fratzke 2017).

Historically voluntary return was posited as the ideal solution for refugees as long as it was safe, consensual and practiced with dignity. It was used throughout the 1960s and 1970s when refugees returned to newly independent states in Africa after successful liberation struggles (Crisp and Long 2016). During the 1990s repatriation was presented as the best solution with more than 10 million people repatriated though this was not always voluntary. The example of Rwandan refugees rounded up and forced to return from Tanzania in 1996 even though they were returning to detention and killings highlights an ostensible solution that is failing refugees and the lack of attention to safety (Crisp and Long 2016). In 2015 just over half a million people were returned to their country of origin while in 2016 the numbers was 667,400 (UNHCR 2018). However, success or failure cannot simply be measured in numbers; what is significant is whether the return is voluntary or forced and whether it is safe and sustainable.

Return or repatriation has traditionally been seen as the end of the refugee cycle. It is the moment when responsibility is returned from the receiving state to the country of origin. Return assumes that the right place for a refugee, and 
their children, is the country of origin. Where refugee situations are protracted return could be to a country that is unfamiliar, such as the children of Afghan refugees who were born and lived only in Iran or in Pakistan. Little is known about what happens to refused asylum seekers post-deportation. As states make the decision to deport, and it is therefore forced, it is part of the antiimmigration arsenal of weapons used globally and can also result in nonrefoulement, where states return someone to a place where his or her life or freedom would be threatened (Coutin 2015; Schuster 2018). The very limited scholarship on post-deportation points to the stigma experienced by deportees and the lack of viable return in the form of economic and social realities (Schuster 2011). Deportation is not the end of the refugee cycle, particularly when return is neither voluntary nor sustainable. Deportation can instead be the beginning of new plans to migrate be it in Asia, Africa, the Americas or Europe (Galvin 2015; Schuster and Majidi 2015; Majidi and Schuster 2019).

The failings of durable solutions are evident in the regular efforts to repackage them. This has included a focus on the root causes of refugee flows, refugee aid and development, Convention Plus, the Framework for Durable Solutions and most recently the Global Compact on Refugees. The Global Compact includes, as its objectives, these durable solutions that continue to fail refugees. Significantly, it does not contain concrete commitments from states to resettle larger numbers of refugees, to ensure routes to seek asylum and gain protection are accessible, or to effectively work with refugees in protracted situations. Hathaway (2019) argues that the Global Compact maintains the status quo, perpetuates the misallocation of resources away from the poorest regions that host the majority of the world's refugees and does nothing to address the lack of global responsibility. This is partly because it relies on states being willing to resettle and to share responsibility in an era when security, borders and restrictions are the norm.

Hathway (2019) proposes a five-stage model, an alternative to the Global Compact, where refugees have 'access' to protection for the first five years, often in region and where mobility and employment in the country of protection is not restricted. If after five years local integration or repatriation were not possible then resettlement would take place outside of the region. Although the model would limit the numbers of refugees in protracted situations and in camps it is not a panacea. First, it requires wealthier states to completely change ingrained and politically expedient policies by taking responsibility both financially and in terms of the numbers resettled. Second the focus is on refugees who are a minority of those in need of protection and in so doing excludes the majority. Thirdly, the five year model of initial protection before local integration, repatriation or resettlement creates a number of problems that were exposed by the Bosnian temporary protection programme in the early 1990s and offers another example of the need to look backwards to learn from the past but also the advantages of cross disciplinary engagement. First is the detrimental impact of uncertainty. Second, it was expected that repatriation would be the end of the refugee cycle but ultimately most were offered permanent residence on humanitarian grounds in the country where temporary protection was given (Bastiki 2018). While protection 
is necessary, refugees also need to have choices and to be involved in decision-making at every stage of the process instead of being treated as undesirable objects to be distributed (Crisp and Long 2016)

Alternatives to durable solutions have been posited with varying responses including territorially based solutions such as 'Refugia' - a self-governing region where refugees live and work (Cohen and Van Hear 2017). A criticism of Refugia and other alternatives to durable solutions has been their formulation in the richest states without meaningful engagement with academics and others in the regions that host the majority of the worlds displaced people (Crawley 2018). There is scope for social scientists to study and evaluate other solutions, including refugee centred approaches, and to try and find ways of moving away from a system that clearly does not work. Proper engagement at the micro level with individuals and the macro level with states and international organisations to facilitate dialogue and better outcomes would be a useful starting point. There is much ethnographic work that could be carried out to better understand the processes of policy formation, the consequences in relation to practice and individual experiences, at the nation state and supra national levels and within organisations.

\section{Borders and bordering practices}

Borders and bordering practices dominate national and international agendas. Border studies has its origins in political science and international relations where the focus was on borders as dividing lines between territories demarcating the boundaries of nation states (Bramillia 2015). However, in the last 30 years, as a consequence of major geo-political changes including the collapse of the Soviet Union and the end of the Cold War, the field has expanded in terms of what is studied, the academic disciplines involved and the concepts used to understand the fluidity of borders. Refugee studies scholars are coming to the table relatively recently but it is an important area of work because borders link to mobility, the labels and categories used to describe and classify those on the move and on the right to seek asylum. Moreover, it is never far from the political debate including state sovereignty but also integration, assimilation and resources. Borders are fluid and mobile, traversing socio-political spaces like the people who try and navigate their way across them. They now extend beyond the nation state and mark out 'hosts and guests across state, regional, racial and other symbolic boundaries' (Brambilla 2015,19).

Border control is high on the policy agendas of most nation states. In the wealthiest countries borders and border controls are technologically sophisticated, tightly managed and well resourced and effectively shut out those seeking refuge (Fitzgerald 2019). Controls include external pre-entry controls such as visas, document checks, surveillance and in Europe shared databases. Borders are also managed through physical barriers - walls, fences and surveillance - and through inspections, patrols and the use of biometric data. Borders are also internal and so even post-entry the threat of document checks, raids, detention and deportation are still present. Borders and bordering practices are everywhere and can prevent access to the 
asylum system. For those who access asylum systems the culture of disbelief influenced by, 'a political context that constructs asylum seekers as liars and cheats, and of asylum destinations as besieged' (Schuster 2018,13) contributes to large numbers of asylum refusals, deportation and ultimately non-refoulement.

External borders are part of the way in which nation states keep out the unwanted and uninvited. They demarcate who is allowed into the state and who is not, who is subjected to suspicion and who is privileged and mobile. Increasingly cross-border surveillance has become an integral part of global governance where the control of crime and migration are inter-twined as 'crimmigration control' (Aas 2011, 332). The EU is an example of regional border co-operation. Measures include Eurodac - the database that stores and shares the fingerprints of asylum seekers for the operation of the Dublin Regulation - and the European Border Surveillance System (Eurosur) that focuses on the external EU borders. According to the European Commission Eurosur aims to, 'increase reaction capability at external borders...to prevent cross-border crime and irregular migration'ii. The statement clearly shows the conflation of crime and migration. However what policy makers fail to address is the correlation between bordering practices that limit regular migration routes and the need for asylum seekers to make irregular and clandestine journeys. It is this that effectively turns refugees into irregular migrants and leads to their criminalization (Schuster 2011).

One of the most visible, contentious and symbolic types of bordering practice is the physical border wall and fences found in every continent. These walls and fences separate the wanted from the unwanted. New walls and fences or extensions to existing ones spring up in response to the movement of people. The summer of 2015 saw Hungary build walls on their borders with Serbia and Croatia while the UK and France have jointly financed a border fence in Calais. As new fences are erected refugees become stuck in a spatial limbo unable to move on, trapped in makeshift encampments, stuck in transit, constrained and contained by fences and security and abandoned in abject conditions. This is a political strategy where those subjected to such conditions are 'kept alive but in a state of injury' (Mbembe 2003, 21). Humans are reduced to bare life, stripped of rights (Agamben 1998) living in 'deathworlds' in conditions of 'the living dead' (Mbembe 2003, 40).

However, states do more than keep people alive in a state of injury, they also kill. The sovereign right to kill, an aspect of state power in modernity, links the politics of race to necropolitcs. As Mbembe notes drawing on slavery and the Holocaust to illustrate,

... race has been the ever present shadow in Western political thought and practice, especially when it comes to imagining the inhumanity of, or rule over, foreign peoples.... In the economy of biopower, the function of racism is to regulate the distribution of death and to make possible the murderous functions of the state $(2003,17)$.

States also expose people to death through inaction (Mbembe 2003; Davies, Isakjee, and Dhesi 2017). A contemporary example is death in the 
Mediterranean where states ignore the risks to refugees and permit death in the name of deterrent (Voutira 2019). The cessation of the Italian-led Mare Nostrum search and rescue operation at the end of 2014 has not been replaced adequately by the NGOs trying to plug the gaps or the EU border agency Frontex operation Triton, which is mainly concerned with border control meaning that there is a massive shortfall in terms of replacing Mare Nostrum. States have moral and ethical responsibility to provide search and rescue (Cusumano and Pattison 2018) but it is negligently inadequate. Italy and Malta have closed their ports to ships transporting refugees (Cusumano and Gombeer 2018). The humanitarian consequences of refusing to allow boats to dock and passengers to disembark is indicative of the internal battles in Europe and one which highlights the disjuncture between national sovereignty and regional co-operation.

It is not just European ports that are closing or European countries that try and prevent people reaching their domestic jurisdictions through the externalization of borders (Campesi 2018). Australia has externalized borders with a presence in sending country ports but also under the guise of Operation Sovereign Borders intercepts, tows back and returns people to their point of origin or removes them to off shore island detention centres where they are incarcerated in closed and unmonitored institutions and denied any access to the Australian asylum system (Nethery and Holman 2016). Detention is on the rise globally - more than 1 million people pass through detention centres each year (Fiske 2016). Island detention forms part of the hidden global detention estate and so those who work on the islands - civil servants, lawyers, advocates, health providers - are not sufficiently included in either public debates or academic literature (Mountz 2011). Nissology is an important but understudied area among refugee studies scholars raising contemporary questions about legal ambiguity, sovereignty, power and enforcement and their intersections with asylum seeking (Mountz 2011).

Detention is also an important aspect of internal border controls and acts not only to exclude and separate but also to hold and to expel the unwanted through deportation. In the UK the Home Office encourages and facilitates the reporting of those suspected as being undocumented migrants through everyday bordering practices. However, the extension of bordering to civil society actors do not just impact on those trying to stay hidden but they can affect everyone and are often applied in a racialised way that ruptures trust and community cohesion (Bloch and McKay 2016; Vaughan-Williams 2008; Yuval-Davis, Wemyss, and Cassidy 2018).

Borders have become political, symbolic and are doubtless blockers to migration but the strategies of forced migrants and of the smugglers and agents who they pay to make their journeys are responsive to changing bordering practices (Mainwaring 2016). The journey itself, as Benezer and Zetter observe, can be 'a profoundly formative and transformative experience' (2014: 302). Journeys have become signifiers of agency as well as sites of resilience and resistance. Journeys are not linear; they can be circuitous, fragmented and can involve long periods of immobility. In fact the journey itself can lead to agency and ethnic solidarity and result in 'ingenious tactics' 
and can lead to 'a transformative space in which migrants realise their potential' (Mainwaring and Brigden 2016, 255-256).

Borders and bordering practices are entwined with the experiences of those who are deciding whether to move, those on the move and those who have moved. Social scientists researching borders - and the associated range of substantive areas that link to borders, including journeys, the right to seek asylum, deportation, detention, including on islands, can offer important insights that traverse not only a whole range of possible substantive areas but also actors and different levels of analysis. Bringing the micro, meso and macro into dialogue will illuminate the struggles that exist between structure and agency and between power and resistance. Moreover, the ethical and moral impacts of policy-making and policy enactment offer opportunities for refugee studies scholars to contribute a critical voice.

Second generation - the longer term impacts of refugee migration The final area to be highlighted is the generational effect of displacement where generation is being used as a marker of kinship descent (Loizos 2007). In refugee studies the vast majority of research is with the refugee generation but the impacts can be inter-generational. There is of course research that includes refugee children in different physical and geographical contexts such as camps, in transit and as unaccompanied minors. This research covers a number of substantive areas such as humanitarian conditions and interventions, human rights, the lack of access to resources such as education and economic opportunities, food security, gender relations and physical and mental health. However, there is a paucity of research that focuses on the lives of those born in the context of refugee families particularly those who have been resettled or have become refugees in wealthier states.

Making generations a central facet of research in refugee studies will highlight the longer-term consequences of refugee migration. For the most part the children of refugees, growing up the context of their birth families, have been subsumed into the wider scholarship on the experiences of second generation people from migrant backgrounds or within the broader analyses of ethnic minority people. As a consequence, little attention has been given to the possible specificities of refugee backgrounds shaping their lives. This will include both the integration context and their family relationships where story telling, memory and community will shape identity, belonging as well as transnational engagement and diasporic linkages.

Second generation people from refugee backgrounds grow up in an integration context that is not only affected by the asylum and refugee policies that their parents will have been subjected to but also by the wider social policy environment. This means that existing theoretical paradigms fail to offer the insights needed to understand some of the specificities of refugee backgrounds in the lives of second generation people while social policy frameworks fail to account for their diversity within service provision. A shift away from grand theories towards a more micro approach based on histories and biographies incorporating a more intersectional approach should be 
central to any analysis (Bloch, 2018).

The limited research suggests that the children of refugees can face greater disadvantage than second-generation children from non-refugee backgrounds due to their parents' pre- and post-migration experiences (Chimienti et al. 2019). This may include pre-migration trauma, experiences of loss as well as post-migration status uncertainty and limbo due to bureaucratic procedures associated with an asylum system that is sometimes protracted. The exclusions associated with poverty and isolation can also be prevalent. Experiences are varied and will depend on the integration context that exposes different outcomes across localities (Crul and Schneider 2010) as well as family circumstances and individual experiences. My own collaborative research with second generation people from refugee backgrounds in the UK, France and Switzerland focused on the experiences of those who were born and grew up in their parent's country of resettlement or country of asylum and found that the asylum polices of the destination country are an important part of the integration context because it affects the institutional arrangements and the systems in place for key services and opportunities such as education, health and employment (Bloch et al. 2015).

In some European countries a central component of asylum policy is compulsory dispersal where asylum seekers are sent to geographical locations around the country for the duration of their asylum case on a nochoice basis. Dispersal is used in a number of countries including the UK, Ireland, Germany, Norway and the Netherlands and it can result in asylum seekers being placed in areas without pre-existing co-ethnic or even multiethnic communities. Presented as a way to ensure integration, by avoiding ethnic clustering, the reality for asylum seekers can be isolation and a lack of access to appropriate services and employment opportunities (Hynes 2011; Fasani, Frattini, and Minale 2017). Little is know about the impact of dispersal on second-generation people although dispersal to areas with high levels of deprivation mean that some grow up in extreme poverty. Moreover, throughout Europe, the prevalence of anti-asylum public discourses that spill over into narratives about security and terror also impact on second generation people who may experience racism and hostility, especially in some dispersal areas where there is little diversity (Hirsch 2018).

Our research in Paris, London and Geneva also highlights the impact of the country, city and local context in shaping experiences and outcomes amongst second generation people. These include the colonial and migration histories of the countries, community formation and networks, social policy and social services and asylum policies. Second generation people from Vietnamese heritages offer insights into the impact of class but also on colonial connections. In France the refugee generation were from educated professional families who had arrived as students and then stayed as refugees after the fall of Saigon in 1975. This was in contrast to those from Vietnamese backgrounds in the UK who were largely from the north, had little or no education and had been resettled from camps in Hong Kong. Their parents were either not working or were working in low paid jobs with long and unsocial hours often in restaurants or take-away shops where English was not 
required for kitchen work. Some of those from the second generation in the UK recalled the isolation in dispersal areas but also the rupturing experienced by secondary migration to urban centres to be nearer others from the same community and to facilitate access to the labour market in co-ethnically owned restaurants for their parents (Bloch and Hirsch 2017; Hirsch 2018).

Socio-economic backgrounds impact on transnational and diasporic engagement because they affect the maintenance of social networks and the capacity for the return visits that are part of identity formation among the second generation from refugee backgrounds (Valentine, Sporton, and Nielsen 2009). The refugee histories of families and the sharing of memories are also important determinants of identity formation and belonging and these can be developed through return visits to the ancestral homeland where plural belongings and formative social and cultural understandings and connections can develop (Bloch and Hirsch 2018). Moreover, the stories told on return visits are an important way through which the second generation people from refugee backgrounds make sense of histories and help them to connect with their extended families, their parents and with their ancestral homeland (Bloch 2018). However visits are complex and for some they can lead to sense of alienation (Blachnicka-Ciacek 2018; Chimienti, Counilh, and Oppipow 2019).

Identity, home and belonging amongst second generation people, and the ways in which these are transmitted and shaped by refugee backgrounds, are areas where social science research would have much more to contribute. Refugee studies scholars can draw on and develop theoretical ideas within social science disciplines and sub-disciplines including transnational and diaspora studies. In addition much more research is required in order to understand the inter-generational impacts of refugee migration and how the past is transmitted within families and communities through stories, memories and silences. There is also scope to explore how the experiences of second generation people are shaped by the integration context including the antiasylum / refugee discourse and everyday experiences of racism, insecurities of status as well as access to community networks and resources. The experiences of the second and subsequent generations should become much more central to the field of study. It allows for comparative approaches, interdisciplinary perspectives and multi-level analyses.

\section{Conclusion}

This paper has presented an overview of the development of the field of refugee studies and the role of social science disciplines in contributing to knowledge. It exposes the limitations of theory and the constraints of international policy, often funded and formulated with the agendas of the wealthier states taking precedence over the realities of contemporary displacement. The paper suggests three crucial areas for social science research in refugee studies going forward. Each substantive area could offer greater insights into international and state-centred responses and their intersections with the everyday. The multi-level analyses that these areas lend themselves to would offer a better understanding of the tensions between different actors and the inter-play of politics, power and agency. 
The first area, durable solutions, continues to fail with every 'new' initiative exposing the on-going limitations that are woefully inadequate in addressing the realities of displacement. Policy has been stuck partly because funding is often clustered in elite institutions in the wealthier countries that can serve their needs of those states and therefore perpetuates the existing status quo (Chimni 2009; Zetter 2019). The second substantive area, borders and bordering practices, highlights the interplay between state power and individual agency but also the racist ideologies formulated during the colonial era, that legitimise restrictive, racialised and exclusionary measures (de Genova 2018). It also exposes the impact of policy and politics - from the local to the global. The spectacle of power is publically enacted but the human cost is un-measurable and the public are increasingly anesthetized to images of overcrowded and unseaworthy boats or the border fences that are now part of landscapes. These borders sweep up everyone but for refugee studies scholars is raises questions about the right to seek asylum, about refugee protection and the fuzziness and fluidity of categories. The third area going forward, the inter-generational aspect of refugee migration, lends itself to a multi-level analysis where integration context - national and local - interacts with families and individuals. New theoretical insights into the specificity of those from refugee backgrounds would enable a critique of the wider literature on assimilation, integration and cohesion. Inter-disciplinary work that would include transnational and diaspora studies that highlight identity and belonging and family memory and story telling would advance discipline based theoretical work. Certainly post-genocide scholarship highlights the need to understand much more about the inter-generational affects of trauma (see for example Hirsch 2008; Kidron 2009).

Regardless of the substantive areas that are researched and developed it is clear that history and interdisciplinary perspectives must inform research and scholarship to ensure the field advances and that the status quo is challenged. Looking forward, refugee studies scholars must be attentive to ways in which knowledge is produced and used. Critical post-colonial scholars (see for example Chimni 2004; 2009 and Samaddar 2016) as well as feminist scholars (see for example Harding 2004; Campbell 2018) argue that epistemic accountability and responsibility should be at heart of all research and scholarship and that an acknowledgment of differing power relations in the production of and use of knowledge is fundamental. These approaches place emphasis on the need for an explicit and reflexive engagement with values in our process of research problem selection and concept building, explicit engagement with the position of researcher and researched in hierarchical power relations, the explicit acceptance of responsibility to those researched and to social justice, and the evaluation of epistemic standards in terms of the transformative values of social justice. For those working within refugee studies from any social science discipline, there is an on-going call for research that incorporates meaningful collaborations with displaced people, scholars, practitioners and policy makers in the regions where the majority of refugees and other forcibly displaced people live so that their expertise frames debates, interventions and theoretical advances. 


\section{References}

Agamben, G. 1998. Homo Sacer: Sovereign Power and Bare Life, Redwood City: Stanford University Press.

Arango, J. 2002. "Explaining Migration: A Critical View." International Social Science Journal 52 (3): 283-296.

Aas, K. F. 2011. "'Crimmigrant' Bodies and Bona Fide Travellers:

Surveillance, Citizenship and Global Governance." Theoretical Criminology 15 (3): 331-346.

Bakewell, O. 2008. "Research Beyond the Categories: The Importance of Policy Irrelevant Research into Forced Migration." Journal of Refugee Studies 21 (4): 432-453.

Bakewell, O. 2010. "Some Reflections on Structure and Agency in Migration Theory." Journal of Ethnic and Migration Studies 36 (10): 1689-1708.

Bastiki, J. 2018. "Temporary Protection Regimes and Refugees: What Works? Comparing the Kuwaiti, Bosnian, and Syrian Refugee Protection Regimes." Refuge 34 (2): 73-84.

Banerjee, P. and R. Samaddar. 2019. 'Why critical forced migration studies has to be critical by nature', in Bloch, A. and G. Donà. (eds.) Forced Migration: Current issues and debates, Abingdon-on-Thames: Routledge, pp. 44-59.

Beirens, H. and S. Fratzke. 2017. Taking Stock of Refugee Resettlement: Policy objectives, practical trade-offs, and the evidence base, Brussels: Migration Policy Institute.

Benezer, G. and R. Zetter. 2014. "Searching for Directions: Conceptual and Methodological Challenges in Researching Refugee Journeys." Journal of Refugee Studies 28 (3): 297-318.

Blachnicka-Ciacek, D. 2018. "Palestine as 'a state of mind': secondgeneration Polish and British Palestinians' Search for Home and Belonging." Journal of Ethnic and Migration Studies 44 (11): 1915-1931.

Bloch, A. 2018. "Talking About the Past, Locating it in the Present: The Second Generation From Refugee Backgrounds Making Sense of Their Parents' Narratives, Narrative Gaps and Silences." Journal of Refugee Studies 31 (4): 647-663.

Bloch, A., M. Chimienti., A.L. Counilh., S. Hirsch., G. Tattolo, G., L. Ossipow, and C. Wihtol de Wenden. 2015. The Children of Refugees in Europe:

Aspirations, Social and Economic Lives, Identity and Transnational Linkages. Final report - working paper. Geneva: SNIS. 
Bloch, A. and G. Donà. 2019. "Forced Migration: Setting the Scene." In Forced Migration: Current Issues and Debates, edited by Bloch, A. and G. Donà, 1-18. Abingdon-on-Thames: Routledge.

Bloch, A. and S. Hirsch. 2017. "The Educational Experiences of the Second Generation from Refugee Backgrounds." Journal of Ethnic and Migration Studies 43 (13): 2131-2148.

Bloch, A. and S. Hirsch. 2018. "Inter-generational Transnationalism: The Impact of Refugee Backgrounds on Second Generation." Comparative Migration Studies doi.org/10.1186/s40878-018-0096-0.

Bloch, A. and S. McKay. 2016. Living on the Margins: Undocumented Migrants in a Global City, Bristol: Policy Press.

Bloch. A., N. Sigona, and R. Zetter. 2014. Sans Papiers: The Social and Economic Lives of Young Undocumented Migrants in the UK, London: Pluto

Brambilla, C. 2015. "Exploring the Critical Potential of the Borderscapes Concept." Geopolitics 20 (1): 14-34.

Campbell, K. 2018. "Producing Knowledge in the Field of Sexual Violence in Armed Conflict Research." Social Politics 25 (4): 469-495.

Campesi, G. 2018. "Seeking Asylum in Times of Crisis: Reception, Confinement, and Detention at Europe's Southern Border." Refugee Survey Quarterly 37 (1): 44-70.

Castles, S. 2003. "Towards a Sociology of Forced Migration and Social Transformation." Sociology 37 (1): 31-34.

Castles, S. 2007. "The Migration-Asylum Nexus and Regional Approaches." In New Regionalism and Asylum Seekers, Challenges Ahead edited by S. Kneebone and F. Rawlings-Sanae, 25-42. London: Berghahn Books.

Chatty, D. and P. Marfleet. 2013. "Conceptual Problems in Forced Migration." Refugee Survey Quarterly 32 (2): 1-13.

Chimienti, M., Bloch, A., Oppiopw, L., and C. Wihtol de Wenden. 2019. "Second Generation from Refugee Backgrounds in Europe." Comparative Migration Studies, 7: 40

https://comparativemigrationstudies.springeropen.com/track/pdf/10.1186/s408 78-019-0138-2

Chimienti, M., Counilh, A-L and L. Oppipow. 2019. "Second Generation From Refugee Backgrounds: Affects and Transnational Ties and Practices to the Ancestral Homeland." In Forced Migration: Current Issues and Debates, edited by Bloch, A. and G. Donà, 145-162. Abingdon-on-Thames: Routledge. 
Chimni, B.S. (2004) 'From Resettlement To Involuntary Repatriation: Towards a critical history of durable solutions to refugee problems', Refugee Survey Quarterly, 23(3): 55-73.

Chimni, B.S. 2009. "The Birth of a 'Discipline: From Refugee to Forced Migration Studies". Journal of Refugee Studies 22 (1): 11-29.

Cohen, R. 2007. "Response to Hathaway." Journal of Refugee Studies 20 (3): 370-376.

Cohen, R. and N. Van Hear. 2017. "Visions of Refugia: territorial and transnational solutions to mass displacement." Planning Theory \& Practice, 18 (3): 494-504.

Coutin, S. 2015. "Deportation Studies: Origins, Themes and Direction." Journal of Ethnic and Migration Studies 41 (4): 671-681.

Crawley, H. 2018. "Why We Need to Protect Refugees From the Big Ideas Deigned to Save Them." Voices: Independent.

https://www.independent.co.uk/voices/refugee-immigration-europe-migrantsrefugia-self-governance-a8467891.html (accessed July 31, 2019).

Crawley, H., Düvell, F., Jones, K., McMahon S and N. Sigona. 2017. Unravelling Europe's Migration Crisis: Journeys Over Land and Sea, Bristol: Policy Press.

Crawley, H. and D. Skleparis. 2018. "Refugees, Migrants, Neither, Both: Categorical Fetishism and the Politics of Bounding in Europe's 'Migration Crisis'”. Journal of Ethnic and Migration Studies 44 (1): 48-64.

Crisp, J. 2002. "No Solutions in Sight: The Problem of Protracted Refugee Situations in Africa." New Issues in Refugee Research, Working Paper, No. 75, Geneva: UNHCR.

Crisp, J. and K. Long. 2016. "Safe and Voluntary Refugee Repatriation: From Principle to Practice." Journal on Human Migration and Security 4 (3): 141147.

Crul, M. and J. Schneider. 2010. "Comparative integration context theory: Participation and belonging in new diverse European cities." Ethnic and Racial Studies 33 (7): 1249-1268.

Cusumano, E. and K. Gombeer. 2018. "In Deep Waters: The Legal, Humanitarian and Political Implications of Closing Italian Ports to Migrant Rescuers." Mediterranean Politics DOI: 10.1080/13629395.2018.1532145

Cusumano, E. and J. Pattison. 2018. "The Non-Governmental Provision of Search And Rescue in the Mediterranean and the Abdication of State Responsibility." Cambridge Review of International Affairs 31 (1): 53-75. 
Davies, T., A. Isakjee, and S. Dhesi. 2017. "Violent Inaction: The Necropolitical Experience of Refugees in Europe." Antipode 49 (5): 12641284.

De Genova, N. 2018. “The "migrant crisis"” as racial crisis: do Black Lives Matter in Europe?" Ethnic And Racial Studies 41 (10): 1765-1782.

De Wind, J. 2007. "Response to Hathaway." Journal of Refugee Studies 20 (3): 381-385.

Erdal, M.B. and C, Oeppen. 2018. "Forced to Leave? The Discursive and Analytical Significance of Describing Migration as Forced and Voluntary." Journal of Ethnic and Migration Studies 44(6): 981-998.

Fasani, F., T. Frattini, and L. Minale. 2017. "(The Struggle for) Refugee Integration into the Labour Market: Evidence from Europe." Centre for Research and Analysis of Migration, Discussion paper series, CDO 16/17, http://www.cream-migration.org/publ uploads/CDP 16 17.pdf

Fiske, L. 2016. "Human Rights and Refugee Protest Against Immigration Detention:Refugees' Struggles for Recognition as Human." Refuge, 32(1). https://refuge.journals.yorku.ca/index.php/refuge/article/view/40380/36380

Fitzgerald, D. S. 2019. Refuge Beyond Reach: How Rich Democracies Repel Asylum Seekers, Oxford: Oxford University Press.

Fitzgerald, D. S. and R. Aran. 2018. "The Sociology of Refugee Migration." Annual Review of Sociology 44: 8.1-8.20.

Galvin, T. 2015. “'We Deport Them but They Keep Coming Back': The Normalcy of Deportation in the Daily Life of 'Undocumented' Zimbabwean Migrant Workers in Botswana." Journal of Ethnic and Migration Studies 41 (4): 617-634.

Gatrell, P. 2017. "Refugees - What's Wrong with History?" Journal of Refugee Studies 30 (2): 170-189.

Harding S. 2004. (ed.) "The Feminist Standpoint Theory Reader." New York and London: Routledge.

Harrell-Bond, B. E.1986. Imposing Aid: Emergency Assistance to Refugees, Oxford: Oxford University Press.

Hathaway, J. C. 2007. "Forced Migration Studies: Could we Agree Just to 'Date?' Journal of Refugee Studies 20(3): 349-369.

Hathaway, J. C. 2019. "The Global Cop-Out." International Journal of Refugee Law XX (XX): 1-14. 
Havinga, T. and A. Böcker. 1999. "Country of Asylum by Choice or by Chance: Asylum-Seekers in Belgium, the Netherlands and the UK." Journal of Ethnic and Migration Studies 25 (1): 43-61.

Hirsch M. 2008. "The Generation of Postmemory." Poetics Today, 29 (1): 103128.

Hirsch, S. 2018. 'Racism, 'Second Generation' refugees and the asylum system', Identities, 26 (1): 88-106.

Hyndman, J. and W. Giles. 2019. "Protracted Displacement: Living on the Edge'." In Forced Migration: Current Issues and Debates, edited by Bloch, A. and G. Donà, 74-87. Abingdon-on-Thames: Routledge.

Hynes, P. 2011. The Dispersal and Social Exclusion of Asylum Seekers: Between Liminality and Belonging, Policy Press, Bristol.

Kidron C.A. 2009. "Toward an Ethnography of Silence: The Lived Presence of the Past In The Everyday Lives of Holocaust Trauma Descendants in Israel." Current Anthropology, 50 (1): 5-27.

Jacobsen, K. and L. Landau. 2003. "The Dual Imperative in Refugee Research: Some Methodological and Ethical Considerations in Social Science Research on Forced Migration." Disasters 27 (3): 185-206.

Kunz, E. F. 1973. "The Refugee in Flight: Kinetic Models and Forms of Displacement." International Migration Review 7 (1): 125-146.

Kunz, E. F. 1981. "Exile and Resettlement: Refugee Theory." International Migration Review 5 (1): 42-51.

Loizos, P. 2007. "Generations in Forced Migration Research: Towards Greater Clarity.” Journal of Refugee Studies 20 (2): 193-209.

Lubkemann, S.C. 2008. "Involuntary Immobility: on a Theoretical Invisibility of Forced Migration Studies." Journal of Refugee Studies 21 (4): 454-475.

Mackenzie, C., C. McDowell, and E. Pittaway. 2007. "'Beyond 'Do No Harm': The Challenges of Constructing Ethical Relationships in Refugee Research.” Journal of Refugee Studies 20 (2): 299-319.

Mainwaring, C. 2016. "Migrant Agency: Negotiating Borders and Migration Controls." Migration Studies 4, 289-308.

Mainwaring, C. and N. Brigden. 2016. "Beyond the Border: Clandestine Migration Journeys." Geopolitics 21 (2): 243-262.

Majidi, N. and Schuster, L. 2019 "Deportation and Forced Return." In Forced Migration: Current Issues and Debates, edited by Bloch, A. and G. Donà, 88105. Abingdon-on-Thames: Routledge. 
Malkki, L. 1992. "National Geographic: The Rooting of Peoples and the Territorialization of National Identity Among Scholars and Refugees." Cultural Anthropology 7 (1): 24-44.

Marfleet, P. 2007. 'Refugees and History: Why we Must Address the Past', Refugee Survey Quarterly 26 (3) 136-148.

Marfleet, P. 2013. "Explorations in a Foreign Land: States, Refugees, and the Problem of History." Refugee Survey Quarterly 32 (2): 14-34.

Massey, D.S., J. Arango., G. Hugo., A. Kouaouci., A Pellegrino, and J.E. Taylor. 1998. Worlds in Motion: International Migration at the End of the Millennium. Oxford: Oxford University Press.

Mbembe, A. 2003. "Necropolitics." Public Culture 15:11-40.

Mountz, A. 2011. "The Enforcement Archipelago: Detention, Haunting, and Asylum on Islands." Political Geography 30:118-128.

Nethery, A. and R. Holman. 2016. "Secrecy and Human Rights Abuse in Australia's Offshore Immigration Detention Centres." The International Journal of Human Rights 20 (7): 1018-1038.

Reed-Hurtado, M. (2013) "The Cartagena Declaration on Refugees and the Protection of People Fleeing Armed Conflict and Other Situations of Violence in Latin America". Geneva: UNHCR.

Richmond, A. 1993. "Reactive Migration: Sociological Perspectives on Refugee Movements." Journal of Refugee Studies 6 (1): 7-24.

Samaddar, R. 2016. A Post-Colonial Enquiry into Europe's Debt and Migration Crisis, Springer.

Scheel, S. and P. Ratfisch. 2014. "Refugee Protection Meets Migration Management: UNHCR as a Global Police of Populations." Journal of Ethnic and Migration Studies 40 (6): 924-941.

Schuster, L. 2011. "Turning Refugees into 'Illegal Migrants': Afghan Asylum Seekers in Europe." Ethnic and Racial Studies 34 (9): 1392-1407.

Schuster, L. and N. Majidi. 2015. "Deportation Stigma and Re-migration." Journal of Ethnic and Migration Studies 41 (4): 635-652.

Schuster, L. 2018. "Fatal Flaws in the UK Asylum Decision-Making System: An Analysis of Home Office Refusal Letters." Journal of Ethnic and Migration Studies DOI:10.1080/1369183X.2018.1552827 
Turton, D. 1996. 'Migrants and Refugees: a Mursi Case Study', in Allen, T. (ed.) In Search of Cool Ground: War, Flight and Homecoming in Northeast Africa. London: James Currey.

UNHCR 2018. Global Trends: Forced displacement in 2017, Geneva: UNHCR.

Valenta, M. and Z. Strabac. 2013. "The Dynamics of Bosnian Refugee Migrations in the 1990s, Current Migration Trends and Future Prospects." Refugee Survey Quarterly 32 (3): 1-22.

Valentine, G., Sporton, D. and Nielsen, K.B. 2009. "Identities and Belonging: A Study of Somali Refugee and Asylum Seekers Living in the UK and Denmark." Environment and Planning D: Society and Space 27 (2): 234-250.

Van Hear, N. 1998. New Diasporas: The Mass Exodus, Dispersal and Regrouping of Migrant Communities, Washington: University of Washington Press.

Van Hear, N., O. Bakewell, and K. Long. 2018. "Push-Pull Plus: Reconsidering the Drivers of Migration." Journal of Ethnic and Migration Studies 44 (6): 927-944.

Van Hear, N., R. Brubaker, and T. Bessa. 2009. "Managing Mobility for Human Displacement: The growing Salience of Mixed Migration." Human Development Research Paper 2009/20 UNDP, http://hdr.undp.org/en/content/managing-mobility-human-development

Vannini, S., R. Gomez, M. Carney, and K. Mitchell. 2019. "Interdisciplinary approaches to Refugee and Migration Studies: Lessons from Collaborative Research to Sanctuary in the Changing Times of Trump." Migration and Society 2 (1): 164-174.

Vaughan-Williams, N. 2008. "Borderwork Beyond Inside/Outside? Frontex, the Citizen-Detective and the War on Terror." Space and Polity 12 (1): 63-79.

Voutira, E. 2019. "Securitizing the Mediterranean? Cross-Border Migration Practices in Greece." In Forced Migration: Current Issues and Debates, edited by Bloch, A. and G. Donà, 60-74. Abingdon-on-Thames: Routledge.

Yuval-Davis N., G. Wemyss, and K. Cassidy. 2018. "Everyday bordering, belonging and the reorientation of British immigration legislation." Sociology 49 (1): 38-55.

Zetter R. 1991. "Labelling Refugees: Forming and Transforming a Bureaucratic Identity." Journal of Refugee Studies 4 (1): 39-62.

Zetter R. 2007. "More Labels, Fewer Refugees: Remaking the Refugee Label in an Era of Globalization." Journal of Refugee Studies 20 (2): 172-192. 
Zetter, R. 2019 "Conceptualising Forced Migration: Praxis, Scholarship and Empirics." In Forced Migration: Current Issues and Debates, edited by Bloch, A. and G. Donà, 19-43. Abingdon-on-Thames: Routledge.

\footnotetext{
${ }^{\mathrm{i}}$ https://www.unrefugees.org/refugee-facts/statistics/

ii https://ec.europa.eu/home-affairs/what-we-do/policies/borders-and-visas/bordercrossing/eurosur_en
} 